Crime, Histoire \& Sociétés / Crime, History \& Societies

Vol. 2, n² | 1998

Histoire de la criminalité et de la justice pénale en Amérique latine / Criminal justice history in Latin America

\title{
Criminal justice history in Latin America : promising notes
}

Ricardo D. Salvatore

\section{OpenEdition}

\section{Journals}

\section{Electronic version}

URL: https://journals.openedition.org/chs/960

DOI: $10.4000 /$ chs. 960

ISSN: 1663-4837

\section{Publisher}

Librairie Droz

\section{Printed version}

Date of publication: 1 June 1998

Number of pages: $5-14$

ISBN: 2-600-00311-8

ISSN: $1422-0857$

\section{Electronic reference}

Ricardo D. Salvatore, "Criminal justice history in Latin America : promising notes", Crime, Histoire \& Sociétés / Crime, History \& Societies [Online], Vol. 2, n² | 1998, Online since 03 April 2009, connection on 23 March 2022. URL: http://journals.openedition.org/chs/960 ; DOI: https://doi.org/10.4000/chs. 960 


\title{
Criminal justice history in Latin America: promising notes
}

\author{
Ricardo D. Salvatore'
}

$\mathrm{Q}$ uite recently, a series of research projects, stemming from various subdisciplines and informed by distinct methodological perspectives, have begun to converge towards a common territory which, for lack of a better name, I shall call crime and justice history. Studies of banditry, prostitution, street violence, policing, prisons, corporal punishment, ideologies of social order, indigenous litigation, the legal profession, and judicial practices - to name only the principal groupings - have opened up a field of inquiry which, in approach, sensibility, and subject matter, seems quite distinct from the old legal history, as it was practiced in Latin America ${ }^{2}$. These new concerns and new sensibilities - gender studies, subaltern or «bottom-up » history, discourse analysis, ethnographies of modernity, the history of the disciplines, questions of hegemony and social order, studies of democratization, etc. - have produced an accumulation of insights and evidence on issues that are, in reality, quite traditional: crime, law, justice, and punishment. Methodologically eclectic and with fuzzy borders, this «new» field seems to be enjoying a period of remarkable vitality. Recent readings and books, international conferences, networks and associations, and journal articles testify to this renewed interest ${ }^{3}$.

1 Ricardo D. Salvatore is Professor of History at the 'Universidad Torcuato Di Tella', currently (1998) Mellon Visiting Professor at Yale University. He is the editor, with Carlos Aguirre, of The Birth of the Penitentiary in Latin America: Essays on Criminology, Prison Reform, and Social Control, 1830-1940 (Austin: University of Texas Press, 1996); and, in collaboration with Gilbert Joseph and Catherine Le Grand, Close Encounters of Empire. The New Cultural History of US-Latin American Relations (Durham: Duke University Press, 1998). Professor Salvatore's articles have appeared in the Journal of Interdisciplinary History, Hispanic American Historical Review, Peasant Studies, Social Science History, Desarrollo Económico, Journal of Historical Sociology, among others.

2 Since the 1920s, Latin American historians such as Ricardo Levene (Argentina), Mario Góngora (Chile), Silvio Zavala (Mexico), Jorge Basadre (Peru) and others have concentrated their efforts on the study of Derecho Indiano, the corpus of legislation developed during the colonial period. Central to their research agendas is the investigation of the continuities and transformations to the colonial legal structure brought about by the independence of Latin America. Trying to underline the importance of liberal and Jacobin ideas in the making of the independence movements, Levene developed the concept of Derecho Patrio (laws enacted by the national governments after independence), triggering a debate about the existence of true differences between these two systems of legislation. For a fairly comprehensive bibliography of this tradition of Legal History see Sánchez Bella (1992, p. 15-31).

3 An international conference held at Yale University in April 1997 ( $₫$ The Contested Terrains of Law, Justice, and Repression in Latin American Historyn) featured an impressive array of papers on the questions related to Crime and Justice History. The largest professional association of Latin America scholars (LASA) has recently opened a permanent section on Law and Justice. Two important collections of papers have appeared recently - Salvatore and Aguirre (1996), and Buffington and Aguirre (1998), and a third is in preparation. Among specialized journals, Delito y Sociedad, published in Buenos Aires, deserves credit for its attempt to circulate current debates concerning issues of crime, penal policy, and social control. 
Without doubt, the gravitation of scholars towards this common territory is rooted in contemporary social and political problems ${ }^{4}$. At a time when questions of crime, law and justice have become crucial to the deepening of democratization in Latin America, growing interest in this area of research is not surprising. But the methodological and thematic insights of the new cultural and social histories have also been influential. The reading of authors such as Michel Foucault, E. P. Thompson, Eric J. Hobsbawm, Joan Scott, Charles Tilly, Norbert Elias, James C. Scott, Jürgen Habermas have stimulated historians to look in judicial and police archives for answers to a variety of problems. Questions of mentalités, popular protest and resistance, gender, subaltern subjectivity and language, everyday practices, popular politics, disciplinary knowledge, and state-civil society relations have prepared the way for rich and innovative ways of approaching the old terrain of law, crime, justice, and punishment. In addition, the renewed interest in colonial studies has added new energy to an already established field: the legal history of colonial Spanish America ${ }^{5}$.

But the attraction of themes related to crime, justice, and repression would not be altogether comprehensible if the findings of this new scholarship did not address issues central to the history of Latin America. Recent work in the field endeavors to understand questions such as: the nature of the state, its institutions and practices; the rights demanded by subaltern subjects with respect to the promises of liberalism; the negotiation of gender spheres, roles, and prerogatives in the face of an apparently hegemonic patriarchal order; the relationship between the letter of the law and the practices of the judicial apparatus; the question of violence as a component or by-product of popular culture; the success or failure (or the ambiguity) of the "civilizing process»; etc. Indeed, it could be argued that the new work illuminates some obscure or insufficiently known aspects of Latin American history, calling into question traditional understandings of the nation, the state, the family, gender relations, elite values, and popular culture.

The debate on the nature of Latin American banditry, for example, has served to rekindle the discussion about the role of the peasantry in national and regional politics. Hobsbawm's model of «social banditry » has been the subject of severe criticism, underlining the economic and political motivations behind the activities of Latin American bandits. But, at the same time, the development of banditry during times of political and social unrest had led other scholars to insist that banditry might have constituted an alternative discourse on state policies, if not a direct confrontation to capitalist accumulation in agriculture ${ }^{6}$.

In similar ways, the study of forms of criminality specific to plantation or slave societies has provided new elements for re-examining the tensions between liberalism and the power in racially divided societies. New works on crime on plantations, on the peculiarity of slave codes, and on the judicial treatment of slave felonies have improved our understanding of slavery as a coercive institution and of the obstacles

- These preoccupations include : police brutality in the context of democratization, the construction of memory after the era of state terror, the question of personal security for rich and poor, social demands for a more effective justice, the drug question, etc.

5 Models of this tradition are Hanke (1949); Parry (1948); Schwartz (1973); MacLachlan (1974); and Burkholder and Chandler (1977).

- See Slatta (1987); Joseph (1990); Aguirre and Walker (1990); Brunk (1996). See also Pereir de Queiroz (1977); Chandler (1988); Valenzuela (1991); Vanderwood (1992). 
faced by liberal reformers in transforming an habitus of rule derived from the «peculiar institution »?

Studies on the control of prostitution and other sexually related offenses have contributed valuable information about the relationship between the emergence and consolidation of modern states in Latin America (during the late nineteenth century) and the concern to control female sexuality ${ }^{8}$. Whether promoted by hygienists, by socialists, by conservatives, by liberals, or by cientificos, the new elites saw prostitution as a major threat to the development of the nation-states in the process of modernization. Hence, they pioneered efforts to regulate prostitutes and eradicate venereal disease which were contemporaneous with similar attempts in Europe and the United States ${ }^{10}$.

The importance of the "positivist moment» for the constitution of the modern disciplinarian state has been underscored by new work on the history of prison reform, criminology, and social control ${ }^{11}$. Apparently, the ascent of positivist criminology was accompanied in Latin America by a «medicalization » of the conception and treatment of social problems, and by the expansion of the policing capacities of the national states. The modernization of prisons and policing procedures coincided both with a reformist attitude towards the working-classes (which in some cases acquired quite a welfare flavor) and with an expansion of bureaucratic procedures of state surveillance, mass statistics, and anthropometric and clinical investigation. The treatment of female offenders, on the other hand, to a large extent escaped the influence of positivist reformers, as religious institutions maintained their control of houses of refuge and correctional facilities ${ }^{12}$.

From different angles, scholars have questioned judicial sources about the nature, characteristics, and motivations of violence in the region. Regarding 'popular violence', the investigation has been wide-ranging and productive, leading to quite challenging re-interpretations of ritual violence, gang political violence, gender violence, social (revolutionary) violence, vigilantism, and other, less overt, forms of violence ${ }^{13}$. Though still insufficient to provide a historically informed topography of violence in the region, and far short of explaining the emergence of these types of violence, this work extended the terrain of discussion to areas beyond the traditional interest in working-class militancy and peasant uprisings. In most of the cases, judicial and police archives have furnished the materials for this new work.

7 See Pereira Machado (1987); Hunold Lara (1988); Malerba (1994); and Trotman (1986).

8 See Ruggiero (1992a).

9 In part, as Kristin Ruggiero (1992b) has argued, the concern to protect masculine notions of honor led to the survival of quite ancient institutions for the control of female sexuality.

10 Important works on prostitution are Guy (1991); Rago (1991); Engel (1989). See also Caulfield (1997); McCreery (1986).

11 Many of the essays in The Birth of the Penitenciary in Latin América deal with this question. See also: Salessi (1995); Engel (1989) and Salvatore (1992). On the influence of race in the state's reformist programs, see Stepan (1991); Zimmerman (1992); and Borges (1993).

12 See Zárate Campos (1996); and Caimari (1997).

13 No list could do justice to the diversity of creative work in this area. On rebellions, see: O'Phelan (1985); Stern (1987); Katz (1988). On everyday forms of violence in contemporary Brazil, see: Scheper-Hughes (1992). On political gang violence, see: Schroeder (1996), and Bergquist, Peñaranda, and Sánchez (1992). On vigilantism, see Huggins (1991). On gender (domestic) violence, see Stern (1995). On the question of ritual violence, see Clendinnen (1987). 
Researchers working on the colonial period have produced interesting results by revisiting the archives of Spanish judicial institutions in the Americas. In particular, there has been a resurgence of the question of the malleability and adaptability of Spanish judicial institutions as an instrument of hegemony vis-à-vis indigenous peoples. Ample judicial discretion, lack of effective controls over lowercourt decisions, and flexibility in procedures are said to have allowed for an important interaction between indigenous and lower-class groups, and Spanish judges $^{14}$. The courts, then, played the role of a «contact zone» between cultures, permitting the gradual construction and dissemination of a peculiar (hybrid) legal culture.

Still, much needs to be done in the area of «legal culture $»$ in the national period. Important transformations took place during the nineteenth century in legislation, institutions, and legal practices ${ }^{15}$. Despite some current interest in the role of the legal profession during the transition from colony to nation and in the practices of lawyers and judges in courts ${ }^{16}$, the question of the transmission of legal concepts to lower-class groups - and of the reception, adaptation, and resistance of these concepts in - «popular culture» - has yet to be addressed. A salient question which deserves our attention is the accessibility and use of judicial institutions by different subaltern groups. Studies of litigation by subaltern groups are still regretfully few ${ }^{17}$. Apart from a handful of studies on African slaves seeking manumission, or on indigenous peoples' legal struggles for land, few studies have assessed the possibilities and obstacles confronting women, workers, and other subalterns in the postindependence courts.

Repression has received some attention. The emergence of a professional and centralized police in the late nineteenth and early twentieth centuries (leading in some cases to the conception of a «scientific» police) seems to have served as an instrument of arbitrary control, segregation, and repression of the popular classes, rather than an instance for achieving orderly social interactions in communities of citizens ${ }^{18}$. The puzzling re-emergence and intensification of torture in the recent past (military dictatorships) have generated an interest among scholars in interpreting and describing regimes of state terror ${ }^{19}$. The extreme psychological and physical violence of the interrogations conducted in clandestine detention camps, scholars agree, has few precedents in the region's history, comparable only to the procedures of the Inquisition in the sixteenth and seventeenth centuries. But this very fact poses the question of the «civilizing process » during the nineteenth and early twentieth centuries. Did Latin America follow the pattern of Europe, in the amelioration of

14 Similar arguments have been put forward by: Cutter (1995); Kellog (1995); Scardaville (1994).

15 Fernando de Trazegnies (1992) has claimed that the period brought about a modernization of legal structures but in ways that did not affect the structures of power. Other important work related to the transformation of law and justice during this period is Flory (1981).

16 Uribe (1995); and Barreneche (1997).

17 Steve Sterns' contention that the litigiosity of indigenous struggles in colonial Peru hindered the development of other, more direct means of fighting colonialism has stimulated studies on the interaction of indigenous peoples in Spanish courts. Similar work for the national period are missing. See Stern (1982). For a contemporary discussion of this question, see Zeitlin and Thomas (1992).

On policing, see Vanderwood (1992); Holloway (1993); Cancelli (1993); Ruibal (1993); Bretas (1995); and Kalmanowiecki (1995).

19

See, for example, Graziano (1992); Taylor (1997); and Andersen (1993). 
publicly inflicted state violence, the long-term reduction of homicide rates, and the rising distaste for corporal punishment and for cruelty to animals ${ }^{20}$ ?

The history of crime and justice in Latin America shows some promising notes at this time: new research results, multiple methodologies and perspectives, and the coming to fruition, in good narrative histories, of concepts debated over decades. Still, there remain some remarkable lacunas in our understanding of law, crime, justice, and punishment. One of the most important unresolved matters concerns the adaptation of legal institutions to the political and social changes brought about by de-colonization, economic modernization, and social revolution. In particular, scholars have still to untangle the effects of mid-nineteenth-century liberalism and latenineteenth-century positivism on the reshaping of legal traditions. The effects of certain currents of ideas on social-reform movements reached and transformed the institutions of the state. Positivism is a case in point, for which much work has been done at the ideological level; but still little is known about its embedding in institutions and social practices. The influence of positivism in re-defining the "social question » at the turn of the century must remain a central preoccupation for Latin American social historians.

Another issue that has been neglected by Latin American historians is the longterm evolution of violence in the region. Violence - that complex, multifaceted, and often intractable phenomenon - needs to be measured, deconstructed, evaluated, and reflected upon with more intensity than in the past, and conclusions sought in a comparative, long-term dimension.

More work is also needed on the interactions between subaltern subjects, state officials, and professional elites in the courts. Scholars need to reconsider the question of the legal competence, experience, and involvement of subaltern subjects at the various stages of the state-building process. The history of policing remains one of the least-explored areas. In particular, the important question of how the state controlled the lower classes on a day-to-day basis deserves more attention than it has received in the past. Together with mass recruitment and elementary education, the police was an essential instrument for the dissemination of concepts of order and discipline, its actions sometimes accompanying, other times undermining, the hegemonic projects of elites.

\section{In this lssue:}

The essays featured in this volume try to address some of these issues and questions. Robert Buffington's contribution sheds light on the transition from the liberal to the revolutionary state and its influence on conceptions of punishment. Going against the grain of established scholarship on the modernization of the Mexican state - and, particularly, against the widely held notion that the 1910-1919 Revolution extended the rights produced by earlier liberal reforms - , Buffington argues that the pressure for modernization has always coexisted with a conservative disposition resulting from the need to control the lower classes.

In 1931 the promises of liberal reformers and those of positivist reformers blended into a hybrid and pragmatic criminal code which augmented the discretionary powers of the judiciary. The code made positivist principles on social defense and individualized punishment compatible with the liberal promises of protection for

20 For a summary of European findings on this question, see Johnson and Monkkonen (1996). 
individual rights (upgraded by the Revolution to social and workers' rights). Recurrent preoccupations among the political class about the need to build the legitimacy of the revolutionary state gave the judiciary branch powers that not even the dictator, Porfirio Díaz, could have imagined. Hybridity and pragmatism were the distinctive features of the legal culture formed by the assemblage of seemingly contradictory traditions.

In her essay, Arlene Díaz provides both quantitative and qualitative evidence of women's use of the judicial system in early republican Venezuela. Women of Caracas, she argues, went to court quite frequently to fight for greater equality with men. The courts, Díaz tells us, being an element of the public sphere, can reveal important aspects of the relationship between males and females in the domestic sphere, a domain often concealed from public scrutiny. As a result, court cases can help us detect and decipher the «hidden transcript» of women's struggles and the motivations which animate these struggles.

While gender conflicts in the courts were already visible in the late-colonial period, the early republican period produced an avalanche of trials concerning the relations of men and women within the household. Two contending sets of rights were ventilated in the courts: men tried to maintain their rights as padres de familia; women defended what they considered were their rights as ciudadanas. What did poor women expect from republican (male-dominated) courts? They wanted the court to force their husbands or lovers to assume greater economic responsibility in the formal or informal marriage contract. They appealed for protection from abusive husbands, seeking in many cases legal separation. They challenged the male privilege, accepted by law and society, of punishing disobedient or unfaithful wives. And, as importantly, they defied the unrealistic condition, imposed by patriarchal norms, that they should remain at home. Poor women interpreted the official rhetoric of the independence leadership as a promise of liberty and equality which could be extended (and needed to be effectively enforced) to the domestic sphere ${ }^{21}$.

Bretas' essay deals with the different attitudes adopted by the Rio de Janeiro police towards women, in the first three decades of the twentieth century. The article's main contribution is that the Rio police, rather than being simply the «sovereign's vigilant eye ", was a world of its own with its own practical rules on when to intervene and what rights to protect. Insufficiently circumscribed or defined by law, the realm of policing was defined and delimited by everyday practice. The police intervened quite frequently in cases involving women, but their actions and positions were influenced by the roles assigned to them by society at large.

The attitude of the police changed with the type of intervention or felony. In the case of the crimes of «defloration », the police acted upon the demand by the victim's relatives. Parents and police authorities cooperated until an extra-judicial solution was reached (in most cases, this solution entailed a compulsory marriage to save the girl's honor). In cases of domestic violence involving couples, the police intervened less and were more tolerant of male violence, supporting by their inaction the husband's authority within the couple. When this authority was waning or non-

21 Gender conflicts as they appeared in the courts - argues Díaz - were transected by class differences. Women of greater wealth and higher status went to court to defend their property, threatened by the inability or avarice of their husbands. Lower-class women, instead, took to court interpersonal conflicts resulting from their relationships with husbands or lovers. These often involved physical abuse and maltreatment, broken promises, the right to work, and female seclusion. 
existent, the police was more protective and helpful towards women. Poor street women, on the other hand, were subject to continuous harassment by the police.

The essay by Carlos Aguirre deals with the reception of positivist criminology in Peru. He argues that, as Lombrosian or biological interpretations of crime lost credibility at the turn of the century, new « social » explanations of crime came to dominate the discourse of the reformist elite. Early followers of Lombroso (Fuentes Castro and Rodríguez), studying inmates at the Lima penitentiary or drawing sketches of famous criminals, developed the image of the Indian «born criminal », reinforcing existing racial prejudices about indigenous peoples. But soon, the construction of indigenous «born criminals» gave way to concerns about ways of reforming multi-ethnic delinquents. Crime was seen more as the product of various social ills - such as prostitution, vagrancy, and - «gamonalism» (a form of peonage) - and less as the result of racial degradation. The emergence of indigenista ideas, in particular, made criminologists aware of the inconsistency between the project of nationbuilding and the denigration and incrimination of indigenous peoples: if Peruvian Indians were unredeemable, then the Peruvian nation would have no future. Thus, without totally dismissing the racial question, criminologists tended to discredit earlier interpretations of crime dependent upon extreme forms of biological determinism. As a consequence, emphasis in policy on the lower-class (now defined not exclusively on racial terms) shifted to education, the policing of manners, and rehabilitative imprisonment.

The four essays published in this issue make a strong case for the vitality of criminal justice history in Latin America. The ground they cover (judicial discretion, gender in the courts, race and positivist criminology, and urban policing) can be considered novel, to the extent that these questions have not been examined, in this light, by other scholars. Though working with quite different materials, the authors share common sensibilities. This can be seen in the attention paid to the complexity and opacity of crime events, in the importance attributed to the analysis of discourse and representation, in the careful consideration of institutional practices, in the recurrent concern with questions of popular and elite values during moments of social and political transformation. These essays should open a dialogue between social historians of crime and justice in Latin America and their colleagues in Europe, North America, and other regions.

\author{
Ricardo D. Salvatore \\ Department of Government and Political \\ Science \\ Universidad Torcuato Di Tella \\ Miñones 2177 \\ 1428 Buenos Aires - Argentina \\ E-mail : rsalvat@utdt.edu.ar
}

\title{
REFERENCES
}

Aguirre, C., Walker, Ch., (eds.), Bandoleros, abigeos y montoneros, Lima, IAA/ Pasado y Presente, 1990.

Andersen, M.E., Dossier Secreto; Argentina's Desaparecidos and the Myth of the «Dirty War», Boulder, Westview, 1993. 
Barreneche, O., Crime and the Administration of Criminal Justice in Buenos Aires, Argentina, 1785-1853, Doctoral diss., University of Arizona, 1997.

Bergquist, Ch., Peñaranda, R., Sánchez, G., Violence in Colombia, Willmington, SR Books, 1992.

Borges, D., 'Puffy, Ugly, Slothful, and Inert': Degeneration in brazilian social thought, 18801940, Journal of Latin American Studies, 1993, $25,2$.

Bretas, M.L., You Can't: The Daily Exercise of Police Authority in Rio de Janeiro: 19071930, Doctoral diss., Milton Keynes, Open University, 1995.

Brunk, S., The sad situation of civilians and soldiers: The banditry of Zapatismo in the Mexican Revolution, American Historical Review, 1996, 101, 2.

Buffington, R., Aguirre, C., (eds.), Reconstructing Criminality in Latin America, Willmington, SR Books, 1998.

Burkholder, M., Chandler, D.S., From Impotence to Authority: The Spanish Crown and the American Audiencias, 1687-1808, Columbia, University of Missouri Press, 1977.

Caimari, L., Whose criminals are these? Church, state patronatos, and the rehabilitation of Female Convicts (Buenos Aires, 1890-1940), The Americas, 1997, 54, 2.

Cancelli, E., O mundo da violencia. A policia da era Vargas, Brasilia, Editora Universidade de Brasilia, 1993.

Caulfield, S., The birth of the Mangue. Race, Nation, and the politics of prostitution in Rio de Janeiro, 1850-1942, in Balderston, D., Guy, D., (eds.), Sex and Sexuality in Latin America, New York, New York University Press, 1997.

Chandler, B.J., King of the Mountain: The Life and Death of Giuliano the Bandit, Dekalb, Northern Illinois University Press, 1988.

Clendinnen, I., Ambivalent Conquests. Maya and Spaniard in Yucatán, 1517-1570, Cambridge, Cambridge University Press, 1987.

Cutter, Ch., The Legal Culture of Northern New Spain, 1700-1810, Albuquerque, University of New Mexico Press, 1995.

Engel, M., Meretrizes e doutores, São Paulo, Brasiliense, 1989.

Flory, T., Judge and Jury in Imperial Brazil, 1808-1871, Austin, University of Texas Press, 1981.

Graziano, F., Divine Violence: Spectacle, Psychosexuality, and Radical Christianity in the Argentine «Dirty War», Boulder, Westview, 1992.

Guy, D., Sex and Danger in Buenos Aires, Lincoln, University of Nebraska Press, 1991.

Hanke, L., The Spanish Struggle for Justice in the Conquest of America, Philadelphia, University of Pennsylvania Press, 1949.

Holloway, T., Policing Rio de Janeiro, Stanford, Stanford University Press, 1993.

Huggins, M., (Ed.), Vigilantism and the State in Modern Latin America, New York, Praeger, 1991.

Hunold Lara, S., Campos da Violencia, Rio de Janeiro, Paz e Terra, 1988.

Johnson, E.A., Monkkonen, E.H., (eds.), The Civilization of Crime, Urbana-Chicago, University of Illinois Press, 1996.

Joseph, G., On the trial of Latin American bandits, Latin American Research Review, 1990, 25,3 .

Kalmanowiecki, L., Military Power and Policing in Argentina, 1900-1955, Doctoral diss., New York, New School for Social Research, 1995.

Katz, F, (Ed.), Riot, Rebellion, and Revolution: Rural Social Conflict in Mexico, Princeton, Princeton University Press, 1988. 
Kellog, S., Law and the Transformation of Aztec Culture, 1500-1700, Norman, University of Oklahoma Press, 1995.

MacLachlan, C., Criminal Justice in Eighteenth-Century Mexico, Berkeley, University of California Press, 1974.

Malerba, J., Os Brancos da Lei, Maringa, Ed. Univ. Maringa, 1994.

McCreery, D., This life of misery and shame: Female prostitution in Guatemala City, 18801920, Journal of Latin American Studies, 1986, 18.

O'Phelan, S., Rebellions and Revolts in Eighteenth Century Peru and Upper Peru, Köln, Böhlau, 1985.

Parry, J.H., The Audiencia of New Galicia in the Sixteenth Century, Cambridge, Cambridge University Press, 1948.

Pereir de Queiroz, M., Os Cangaceiros, São Paulo, Liv. Duas Cidades, 1977.

Pereira Machado, M.H., Crime e escravidao, São Paulo, Brasiliense, 1987.

Rago, M., Os Prazeres da Noite, São Paulo, Paz e Terra, 1991.

Ruggiero, K., Honor, maternity, and the disciplining of women: Infanticide in late nineteenthcentury Buenos Aires, Hispanic American Historical Review, 1992, 72, 3 (a).

Ruggiero, K., Wives on deposit: Internment and the preservation of husbands' honor in late nineteenth-century Buenos Aires, Journal of Family History, 1992, 17, 3 (b).

Ruibal, B., Ideología y control social: Buenos Aires, 1880-1920, Buenos Aires, Centro Editor de América Latina, 1993.

Salessi, J., Médicos, maleantes y maricas, Rosario, B. Viterbo, 1995.

Salvatore, R., Aguirre, C., (eds.), The Birth of the Penitentiary in Latin America, 1830-1940, Austin, University of Texas Press, 1996.

Salvatore, R., Criminology, prison reform, and the Buenos Aires working class, Journal of Interdisciplinary History, 1992, 23, 2.

Sánchez Bella, I., Historiografía Jurídica Indiana, in Sánchez Bella, I., de la Hera, A., and Díaz Rentería, C., (eds.), Historia del Derecho Indiano, Madrid, Mapfre, 1992, p. 15-31.

Scardaville, M., (Habsburg) law and (Bourbon) order: State authority, popular unrest, and the criminal justice system of Bourbon Mexico City, The Americas, 1994, $50,4$.

Scheper-Hughes, N., Death Without Weaping, Berkeley, University of California Press, 1992.

Schroeder, M., Horse thieves to rebel dogs: Political gang violence and the state in the Western Segovias, Nicaragua, in the Time of Sandino, Journal of Latin American Studies, $1996,28,2$.

Schwartz, S.B., Sovereignty and Society in Colonial Brazil: The High Court of Bahia and Its Judges, 1609-1751, Berkeley, University of California Press, 1973.

Slatta, R., Bandidos. The Varieties of Latin American Banditry, Westport, Greenwood Press, 1987.

Stepan, N., The Hour of Eugenics, Ithaca, Cornell University Press, 1991.

Stern, S., Peru's Indian Peoples and the Challenge of Spanish Conquest, Madison, University of Wisconsin Press, 1982.

Stern, S., (Ed.), Resistance, Rebellion and Conciousness in the Andean Peasant World, Madison, University of Wisconsin Press, 1987.

Stern, S., The Secret History of Gender, Chapel Hill, University of North Carolina Press, 1995.

Taylor, D., Disappearing Acts: Spectacles of Gender and Nationalism in Argentina's "Dirty War», Durham, Duke University Press, 1997.

Trazegnies, F. de, La idea del derecho en el Perú republicano en el siglo XIX, Lima, Pontificia Universidad Católica del Perú, 1992. 
Trotman, D., Crime in Trinidad, Knoxville, University of Tennesse Press, 1986.

Uribe, V., The Lawyers and New Granada's Late Colonial State, Journal of Latin American Studies, 1995, $27,3$.

Valenzuela, J., Bandidaje rural en Chile central: Curicó, 1850-1900, Santiago, Archivos y Museos, 1991.

Vanderwood, P., Disorder and Progress: Bandits, Police and Mexican Development, Wilmington, Scholarly Resources, 1992.

Zárate Campos, M.S., Vicious women, virtuous women: The female delinquent and the Santiago de Chile correctional house, 1860-1900, in Salvatore, R., Aguirre, C., (eds.), The Birth of the Penitentiary in Latin America, 1830-1940, Austin, University of Texas Press, 1996, p. 78-100.

Zeitlin, J.F., Thomas, L., Spanish justice and the indian cacique: Disjuntive political systems in sixteenth-century Tehuantepec, Ethnohistory, 1992, $39,3$.

Zimmerman, E., Racial ideas and social reform: Argentina, 1890-1916, Hispanic American Historical Review, 1992, 77, 1. 